\title{
Cross-linked poly(vinyl alcohol)/sulfonated nanoporous silica hybrid membranes for proton exchange membrane fuel cell
}

\author{
Hossein Beydaghi · Mehran Javanbakht • \\ Alireza Badiei
}

Received: 27 December 2013/Accepted: 8 March 2014/Published online: 29 April 2014

(C) The Author(s) 2014. This article is published with open access at Springerlink.com

\begin{abstract}
Organic-inorganic nanocomposite membranes of poly(vinyl alcohol) (PVA) and nanoporous silica containing sulfonic acid groups are synthesized in order to increase the proton conductivity, water retention and thermal stability of membrane. The cross-linked PVA/ SBA-15-propyl- $\mathrm{SO}_{3} \mathrm{H}$ nanocomposite membrane was prepared by solution casting method. Infrared spectroscopy and scanning electron microscopy are used to characterize and confirm the structure of PVA and the cross-linked membranes. The impedance spectroscopy, water uptake and thermal stability of membranes are investigated to confirm their applicability in fuel cells. It was found that the cross-linked PVA/SBA-15-propyl- $\mathrm{SO}_{3} \mathrm{H}$ nanocomposite membrane appears to be a good candidate for using in PEM fuel cell.
\end{abstract}

Keywords Nanocomposite membrane $\cdot$ Sulfonated nanoporous silica Proton conductivity · Fuel cell · poly(vinyl alcohol)

\section{Introduction}

There is a growing worldwide concern about energy sources and supplies. Due to the increasing worries on the diminution of fossil fuel reserves and contamination of climate, fuel cell technologies have received much

H. Beydaghi · M. Javanbakht ( $\square$ )

Department of Chemistry, Amirkabir University of Technology,

Tehran, Iran

e-mail: mehranjavanbakht@gmail.com

A. Badiei

School of Chemistry, College of Science, University of Tehran,

Tehran, Iran attention in recent decades because of their high efficiencies and low emissions [1]. In the fuel cells, chemical energy directly converts to electrical energy. There are several kinds of fuel cells, being grouped according to their ion transport medium. This paper focuses on proton exchange membrane (PEM) fuel cells. The heart of the PEM fuel cell is membrane [2]. The traditional membranes used in PEMFC are perfluorosulfonic polymers such as Nafion, a polymer developed by DuPont de Nemours in the late 1960s [3]. Nafion has high electrochemical properties and good proton conductivity. However, the operation at temperatures below $80{ }^{\circ} \mathrm{C}$, methanol crossover and high cost have limited its further application [4, 5].

In the last decades, several methods such as polymer blends, cross-linked polymers and organic-inorganic composite membranes have been proposed to find Nafion alternatives in proton exchange membranes (PEMs). Recent literature describes synthesizes of the organicinorganic composite membranes by incorporations of hydrophilic inorganic phases such as silicon oxide [6], zeolite [7], metal oxide [8], zirconium phosphates [9], heteropolyacids [10], SBA-15 [11] and nano silica [12] in the commercial Nafion or different organic polymers. There is an extensive literature reporting physical, chemical, thermal, mechanical and operational data for modification of the chemical composition of polymer membranes by several groups.

Yang et al. [13] prepared the cross-linked composite membranes of PVA and MMT. It was found that the proton conductivity of membrane increases from 0.0433 to 0.0623 $\mathrm{S} \mathrm{cm}{ }^{-1}$ with addition of $10 \%$ wt MMT at $60{ }^{\circ} \mathrm{C}$. Guzman et al. [14] prepared the porous silica/Nafion composite membranes and tested under high temperature fuel cell operating conditions $\left(140^{\circ} \mathrm{C}\right)$. It was found that with the increase in temperature (above $100^{\circ} \mathrm{C}$ ), the power density 
and cell resistance decrease due to membrane dehydration. This organized silica enhances the proton conductivity of membrane at high temperatures up to $100{ }^{\circ} \mathrm{C}$; this improvement is related to the aligned porous channels in the silica [14].

Presently, we introduced new type of nanocomposite membranes for application in PEMFCs. A cross-linked PVA/PSA-g-SN composite polymer membrane was synthesized and demonstrated for PEMFCs [12, 15]. It was found that grafting of sulfonated monomer onto the silica nanoparticles enhances various properties, for example, proton conductivity, water uptake and tensile strength in membranes. A cross-linked PVA and phenyl sulfonated silica were prepared and characterized as proton exchange membrane for PEMFC [16]. It was found that the composite membranes have a higher water retention and thermal stability than that of Nafion 117, perhaps because of responsibility of both acidic groups and nanoporous structure of silica additive. Nafion/ $/ \mathrm{Fe}_{2} \mathrm{TiO}_{5}$ nanocomposite membranes for proton exchange membrane fuel cells (PEMFCs) were investigated and showed a higher water uptake, proton conductivity and thermal stability compared with the pure commercial Nafion membranes [17].

PVA membranes have shown relatively good properties under fuel cell circumstances such as good thermal stability, good chemical resistance, film forming ability, high hydrophilicity, high mechanical property, good water uptake and low cost [18]. With a high density of functional -OH groups, PVA also has potential for chemical crosslinking. However, PVA is highly swelling and even dissoluble in water and its properties must be improved with cross-linker. The content of added cross-linker must be controlled because if too much cross-linker is added the membrane construction becomes compact and proton conductivity decreases and if cross-linker is added less than needed, the membrane does not have enough mechanical stability to use in fuel cell. The content of added crosslinker is obtained with trial and error method.

In this work, SBA-15-propyl- $\mathrm{SO}_{3} \mathrm{H}$ was used to produce the nanocomposite membrane used in PEM fuel cells. Porous silica is one of the most commonly used fillers for proton exchange membranes. The incorporated, sulfonated nanoporous silica with high surface area in an organic polymer matrix enhances water uptake and conductivity properties [16]. The sulfonic acid groups can help to speed up proton transport through nanopore channels. Propyl sulfonic acid groups can be covalently incorporated into nanoporous silica [19]. SBA-15-propyl- $\mathrm{SO}_{3} \mathrm{H}$ has hexagonal structure, very large surface area, ordered pore structure and extremely narrow pore size distribution with easily accessible acid sites. All of the explained properties are desirable properties important for use in proton exchange membrane applications. These properties of nanoporous silica help to increase water retention in membranes. A membrane with higher water retention can offer more opportunity for protons to transfer through the membrane, leading to higher proton conductivity [20]. The conductivity of SBA-15-propyl- $\mathrm{SO}_{3} \mathrm{H}$ was above $10^{-2} \mathrm{~S} / \mathrm{cm}$ at room temperature [21]. In this work, nanocomposite membrane composed of PVA, glutaraldehyde and SBA-15propyl- $\mathrm{SO}_{3} \mathrm{H}$ has been prepared by solution casting method. This is an approach to add functionalized nanoporous filler into polymer for studying the water uptake, proton conductivity, morphology, and thermal stability of nanocomposite membranes.

\section{Methods}

Materials

Poly (vinyl alcohol), PVA, $+99 \%$ hydrolyzed, with an average molecular weight of 130,000, Pluronic P123 triblock copolymer and $25 \mathrm{wt} \%$ solution of glutaraldehyde (GLA) in water were purchased from Sigma-Aldrich. Tetraethylorthosilicate (TEOS), 3-aminopropyltrimethoxysilane (APTES), $N, N^{\prime}$-dicyclohexylcarbodiimide, hydrochloric acid and organic solvents were obtained from Merck. These solvent were used as received without further purification.

\section{Synthesis of SBA-15}

SBA-15 was prepared according to the literature procedure [22]: $4 \mathrm{~g}$ of Pluronic P123 triblock copolymer surfactant $\left(\mathrm{EO}_{20} \mathrm{PO}_{70} \mathrm{EO}_{20}\right)$ dissolved in $\mathrm{HCl} 2 \mathrm{M}$ and tetraethylorthosilicate was added to solution. The mixture was stirred at $40{ }^{\circ} \mathrm{C}$ for $8 \mathrm{~h}$. The reaction mixture was then aged for $15 \mathrm{~h}$ at $100{ }^{\circ} \mathrm{C}$ The mole fraction of this component was 1 TEOS:0.0168 P123:5.854 HCl:162.681 $\mathrm{H}_{2} \mathrm{O}$. The obtained white product was filtered, washed by deionized water for several times and dried under vacuum. Calcination of product was performed in oven at $550{ }^{\circ} \mathrm{C}$ for $6 \mathrm{~h}$ to remove the triblock copolymer organic component.

\section{Synthesis of SBA-15-propyl- $\mathrm{SO}_{3} \mathrm{H}$}

SBA-15 was dried at $100{ }^{\circ} \mathrm{C}$ for $3 \mathrm{~h}$ under vacuum condition. A mixture containing dry SBA-15 $(5 \mathrm{~g})$ and dry toluene $(100 \mathrm{ml})$ reached the reflux temperature. 3-(Trimethoxysilyl)-1-propanethiol $(7 \mathrm{ml})$ was added to the reaction mixture. Reflux was continued for $24 \mathrm{~h}$ (Scheme 1). The mixture was filtered and the white powder product (SBA-15-propyl-SH) washed with ether and dichloromethane in soxhlet extractor for $6 \mathrm{~h}$. Anchored mercaptopropyl groups must be post synthetically treated 
Scheme 1 Mercaptopropyl grafting on the SBA-15 surface and postoxidation treatment
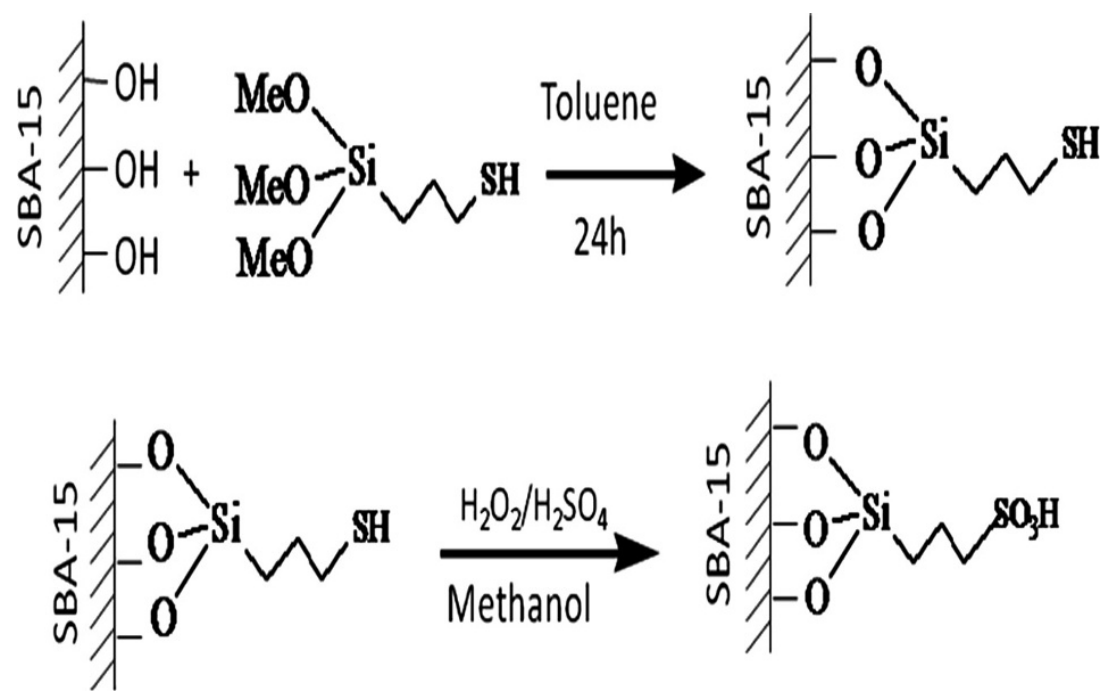

Table 1 Composition of different membranes in this study

\begin{tabular}{llll}
\hline Membranes & PVA & GLA & SBA-15--SO ${ }_{3} \mathrm{H}$ \\
\hline M1 & $100^{\mathrm{a}}$ & - & - \\
M2 & 95 & 5 & - \\
M3 & 95 & - & 5 \\
M4 & 90 & 5 & 5 \\
\hline
\end{tabular}

${ }^{a}$ Weight percentage

to yield acid active sulfonic groups (SBA-15-propyl$\mathrm{SO}_{3} \mathrm{H}$ ). This treatment implies oxidation with a large excess of an oxidant mainly hydrogen peroxide in methanol.

\section{Preparation of membranes}

Four membranes containing PVA, PVA/GLA, PVA/SBA15-propyl- $\mathrm{SO}_{3} \mathrm{H}$ and PVA/GLA/SBA-15-propyl- $\mathrm{SO}_{3} \mathrm{H}$ were synthesized and named $\mathrm{M}_{1}-\mathrm{M}_{4}$, respectively (Table 1). At first, appropriate weight of PVA and SBA15-propyl- $\mathrm{SO}_{3} \mathrm{H}$ was dissolved in deionized water under stirring, respectively. The resulting solution was stirred for $1 \mathrm{~h}$ at $80-90{ }^{\circ} \mathrm{C}$ until the solution mixture became a homogeneous low viscous liquid. Then $1 \mathrm{ml}$ GLA was added into the viscous mixture polymer solution to carry out the cross-linking reaction. The solution stir till the temperature of solution was slowly decreased to room temperature. Finally, $60 \mathrm{mg}$ of $2 \mathrm{M} \mathrm{H}_{2} \mathrm{SO}_{4}$ was added to the solution as a catalyst for the cross-linking reaction. The resulting viscous polymer solution was casted onto a glass plate. The resultant solution underwent freeze-thaw cycles in order to enhance mechanical property and elasticity [23, 24]. The thickness of the wet nanocomposite membrane is about $250-300 \mu \mathrm{m}$.
Apparatus

The structures of SBA-15-propyl- $\mathrm{SO}_{3} \mathrm{H}$-based membranes were characterized by ATR-FTIR spectra in the range of $4,000-600 \mathrm{~cm}^{-1}$ and recorded with a Bruker Equinox 55 using an attenuated total reflectance (ATR, single reflection) accessory purged with ultra dry compressed air. Thermal stability of the membranes was investigated with Mettler DSC 823 in the range -70 to $300{ }^{\circ} \mathrm{C}$ and nitrogen flow. The surfaces of the nanocomposite membranes were analyzed by high-resolution scanning electron microscopy (SEM, XL300 philips). Proton conductivity of membranes calculates by AC impedance spectroscopy over the frequency of $10-10^{7} \mathrm{~Hz}$ with $50-500 \mathrm{mV}$ oscillating voltage and $10 \mathrm{mV}$ amplitude. Structures of nanoporous materials were investigated with $\mathrm{N}_{2}$ adsorption-desorption isotherm measurements at $77 \mathrm{~K}$ with a BELSORP-mini, BEL Japan.

Water uptake measurements

The membranes were dried at high temperature in oven, weighed, soaked in deionized water for $24 \mathrm{~h}$ at room temperature and reweighed. Water uptake of nanocomposite membrane was calculated from this formula:

$\mathrm{WU}=\frac{m_{\mathrm{wet}}-m_{\mathrm{dry}}}{m_{\mathrm{dry}}} \times 100 \%$

In this formula, $m_{\text {wet }}$ is the weight of the wet membranes and $m_{\mathrm{dry}}$ is weight of the dry membranes.

Conductivity measurement

Proton conductivities of nanocomposite membranes were measured by AC impedance method. At first, the membranes were soaked in deionized water for $24 \mathrm{~h}$ until sufficiently wet and saturated. Then, the membrane was cut 
into Sections $2 \times 0.5 \mathrm{~cm}$ and sandwiched between two gold electrodes on the cell. The conductivity of membrane was calculated from the following equation: $\sigma=\mathrm{L} / \mathrm{RA}$, where $\sigma$ is proton conductivity $(\mathrm{S} / \mathrm{cm}), \mathrm{L}$ is membrane thickness $(\mathrm{cm})$, A is surface area of electrodes $\left(\mathrm{cm}^{2}\right)$ and $\mathrm{R}$ is membrane resistance $(\Omega)$.

\section{Results and discussion}

\section{$\mathrm{N}_{2}$ Adsorption}

The synthesized nanoporous silica has a high surface area. Surface area $\left(\mathrm{S}_{\mathrm{BET}}\right)$ of this nanoporous materials is determined by $\mathrm{N}_{2}$ physisorption technique (BET method). $\mathrm{N}_{2}$ adsorption isotherms of SBA-15 and SBA-15-propyl- $\mathrm{SO}_{3} \mathrm{H}$ are shown in Fig. 1 and show that nanoporous silica exhibits a well-defined step with a hysteresis loop corresponding to the filling of the nanopores by capillary condensation. Table 2 shows the surface area, pore volume and pore diameter before and after sulfonation of SBA-15 surface. The decrease in pore sizes and pore volumes confirmed a high ordering of the $\mathrm{SO}_{3} \mathrm{H}$ groups inside the pores and consequently an increase in number of the $\mathrm{SO}_{3} \mathrm{H}$ species.

\section{Infrared spectroscopy}

The structure of SBA-15-propyl- $\mathrm{SO}_{3} \mathrm{H}$ was characterized by IR spectroscopy as shown in Fig. 2. The band at around $1,600 \mathrm{~cm}^{-1}$ could be related to bending vibrations of surface $\mathrm{O}-\mathrm{H}$ groups and water molecules occluded in the pores [25]. Vibrations relating to the $\mathrm{O}-\mathrm{H}$ stretching in $\mathrm{SO}_{3-}$ $\mathrm{H}$ groups are also seen in spectra at $3,380 \mathrm{~cm}^{-1}$. In addition,

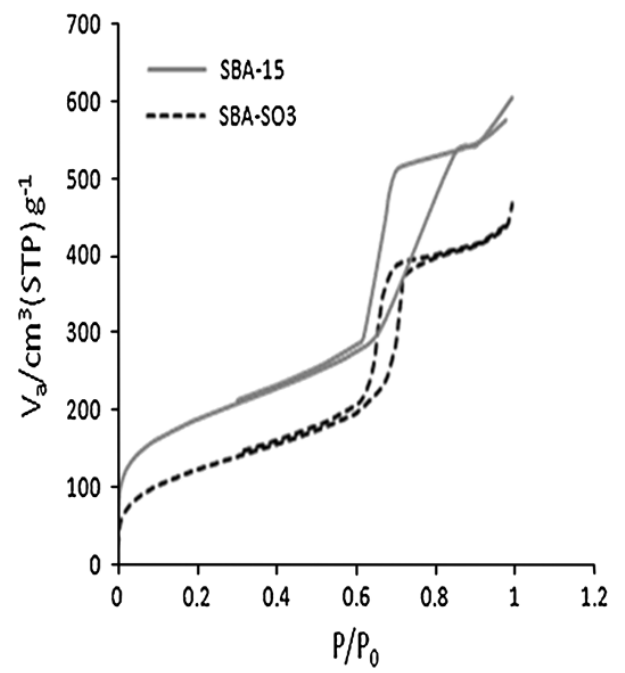

Fig. $1 \mathrm{~N}_{2}$ adsorption-desorption isotherms obtained for SBA-15 and SBA-15-propyl- $\mathrm{SO}_{3} \mathrm{H}$
Table 2 Porosimetry values for SBA-15 and SBA-15-RSO3H

\begin{tabular}{llll}
\hline $\begin{array}{l}\text { Nanoporous } \\
\text { silica }\end{array}$ & $\begin{array}{l}\text { Surface } \\
\text { area }\left(\mathrm{m}^{2} \mathrm{~g}^{-1}\right)\end{array}$ & $\begin{array}{l}\text { Pore volume } \\
\left(\mathrm{cm}^{3} \mathrm{~g}^{-1}\right)\end{array}$ & $\begin{array}{l}\text { Pore diameter } \\
(\mathrm{nm})\end{array}$ \\
\hline SBA-15 & 649.4 & 0.806 & 6.2 \\
$\mathrm{SBA}-15-\mathrm{RSO}_{3} \mathrm{H}$ & 440.9 & 0.660 & 6.0 \\
\hline
\end{tabular}

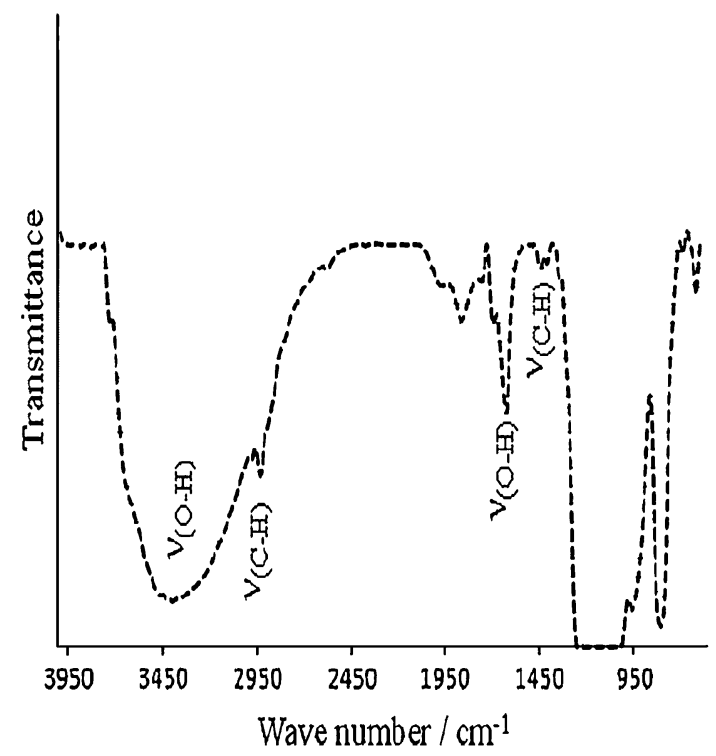

Fig. 2 Vibrational modes of SBA-15-propyl- $\mathrm{SO}_{3} \mathrm{H}$

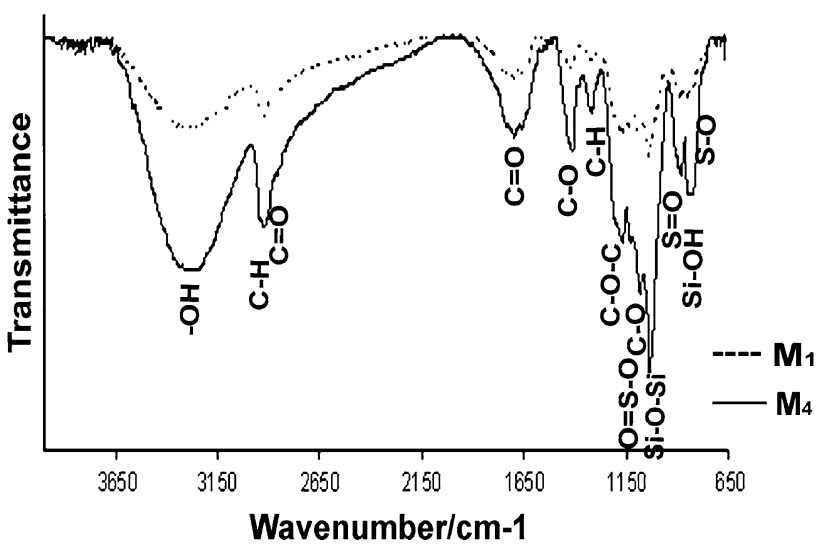

Fig. 3 ATR spectra of the $M_{1}$ and $M_{4}$ membranes

the sample has small bands around 2950 and $1,450 \mathrm{~cm}^{-1}$ due to $\mathrm{C}-\mathrm{H}$ stretching of methylene groups.

Figure 3 shows the attenuated total reflectance (ATR) spectroscopy of $\mathrm{M}_{1}$ and $\mathrm{M}_{4}$ membranes. The $\mathrm{M}_{1}$ membrane illustrates a characteristic absorbance at $3,297 \mathrm{~cm}^{-1}(-\mathrm{OH}$ stretching), $2,921 \mathrm{~cm}^{-1}$ (symmetric $-\mathrm{CH}_{2}-$ ), 1,422 and $1,093 \mathrm{~cm}^{-1}$ for $\mathrm{C}-\mathrm{O}$ group [16]. The bands occurring at around $3,200 \mathrm{~cm}^{-1}$ (characteristic of $\mathrm{O}-\mathrm{H}$ stretching vibration) are corresponding to the $\mathrm{O}-\mathrm{H}$ stretching frequency, which indicates the presence of hydroxyl groups. 
After cross-linking with GLA, intensity of the O-H stretching vibration band is reduced and shifted to a higher wave number [26]. The cross-linked membrane exhibits the characteristic bands at around $1,200-1,250 \mathrm{~cm}^{-1}$ due to the $\mathrm{C}-\mathrm{O}-\mathrm{C}$ group between the alcohol groups of PVA and the aldehyde groups of GLA [27]. The absorption peak at $2,870 \mathrm{~cm}^{-1}$ can confirm the free aldehyde groups [26]. The presence of sulfonic acid group in $\mathrm{M}_{4}$ membrane was confirmed by the characteristic asymmetric and symmetric $\mathrm{S}=\mathrm{O}$ stretching vibrations at 1,145 and $1,030 \mathrm{~cm}^{-1}$. Also, the absorption band at $\sim 830 \mathrm{~cm}^{-1}$ identifies existence of the S$\mathrm{O}$ stretching of $\mathrm{SO}_{3} \mathrm{H}$ groups [28]. The band characteristics of the SBA-15 matrix were observed at $800 \mathrm{~cm}^{-1}(\mathrm{Si}-\mathrm{O}-\mathrm{Si}$, symmetric vibration) and $1,050 \mathrm{~cm}^{-1}(\mathrm{Si}-\mathrm{O}-\mathrm{Si}$, asymmetric vibrations). It is clear that $\mathrm{Si}-\mathrm{O}-\mathrm{Si}$ groups are results of condensation reaction between hydrolyzed silanol groups. A further characteristic stretch found in PVA/GLA/SBA-15propyl- $\mathrm{SO}_{3} \mathrm{H}$ membrane is present at $883 \mathrm{~cm}^{-1}$ representing silanol O-H groups [29, 30].

\section{Water uptake}

It is well known that water uptake and water retention have important effect on the transport behavior and mechanical properties of a proton exchange membrane. The proton conductivity will increase by increasing water uptake because the mobility of protons in the water phase increases with increasing water content. The water uptake of the membranes was tested and the results are shown in Table 3.

From Table 3, water uptake increased with increasing the content of SBA-15-propyl- $\mathrm{SO}_{3} \mathrm{H}$ in polymer due to decreased cross-linked agent. It can be observed that an increase in sulfonated nanoporous silica content in the nanocomposite membrane leads to a substantial increase in water uptake of the membrane because of the increase in density of functional groups enhancing the porous volume and water retention in the membrane phase [31].

Sulfonation of nanocomposite membrane has a significant impact on water uptake, which in turn determines proton conductivity and mechanical properties of the membrane. The- $\mathrm{SO}_{3} \mathrm{H}$ groups of nanoporous silica increased water uptake by increasing the hydrophobic surface property. The sulfonic acid groups attracted the $-\mathrm{OH}$ groups of PVA to reverse the $-\mathrm{SO}_{3} \mathrm{H}$ groups to the membrane interior. The high hydrophilic character of

Table 3 Water uptakes of different membranes sulfonic acid groups, the high surface area and porous volume of nanoporous silica and the stronger interactions between the absorbed water and the modified polymer contribute to increase the water uptake. The GLA decreases the water content because the membrane structure is more compact with addition of cross-linker [32].

\section{Thermal properties}

The differential scanning calorimetry (DSC) thermograms of the nanocomposite membranes are shown in Fig. 4. The endothermic peaks appeared at 120-165, 195-215, and 150- $185^{\circ} \mathrm{C}$, which corresponded to the melting temperature $\left(T_{\mathrm{m}}\right)$ of the pure PVA, PVA/GLA and PVA/GLA/ SBA-15-propyl- $\mathrm{SO}_{3} \mathrm{H}$ membranes. These results show that membranes have several melting points and indicate different crystal structures in nanocomposite membranes.

It was found that the melting temperature, $T_{\mathrm{m}}$, of the cross-linked PVA/GLA membranes shifted toward higher temperature when the PVA membrane was cross-linked with GLA, which is related to the compacted structure of membrane with addition of cross-linker. The melting temperatures were shifted toward lower temperature region when the amounts of modified SBA-15 fillers were added increasingly. The $T_{\mathrm{m}}$ depression of a crystalline component means that the formation of a crystal is suppressed by the interaction between two blend components. The amorphous structure of silica-based materials can decrease the melting temperature of membranes.

\section{Morphological studies}

Figure 5 shows SEM images for the surfaces of nanocomposite membranes $\left(\mathrm{M}_{1}\right.$ and $\left.\mathrm{M}_{4}\right)$. The effect of SBA-15-

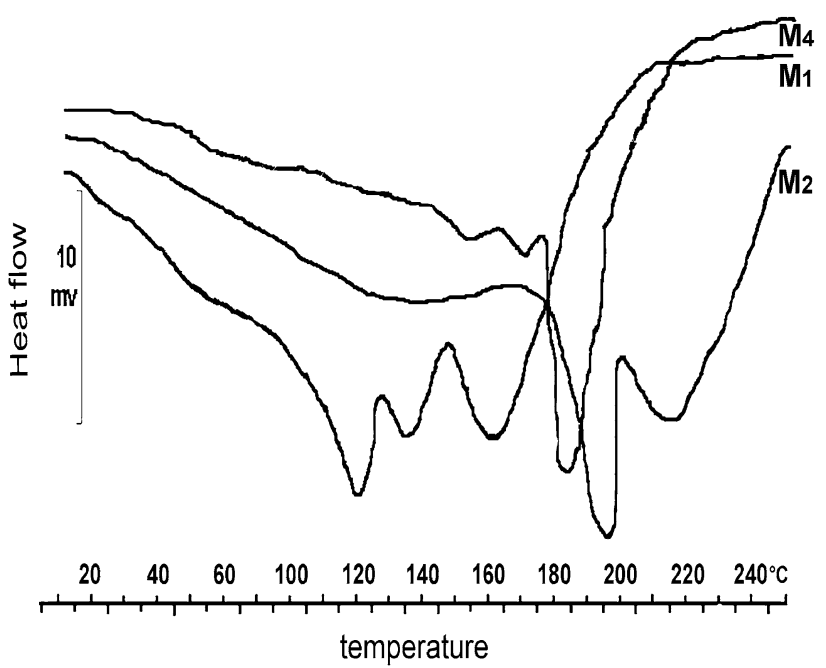

Fig. 4 DSC thermograms of the composite membranes

\begin{tabular}{lr}
\hline Membranes & Water uptake (\%) \\
\hline M1 & 180 \\
M2 & 65 \\
M3 & 235 \\
M4 & 80 \\
\hline
\end{tabular}


Fig. 5 SEM images of the surfaces morphology of $\mathrm{M}_{1}$ (a) and $\mathrm{M}_{4}$ (b) composite membranes
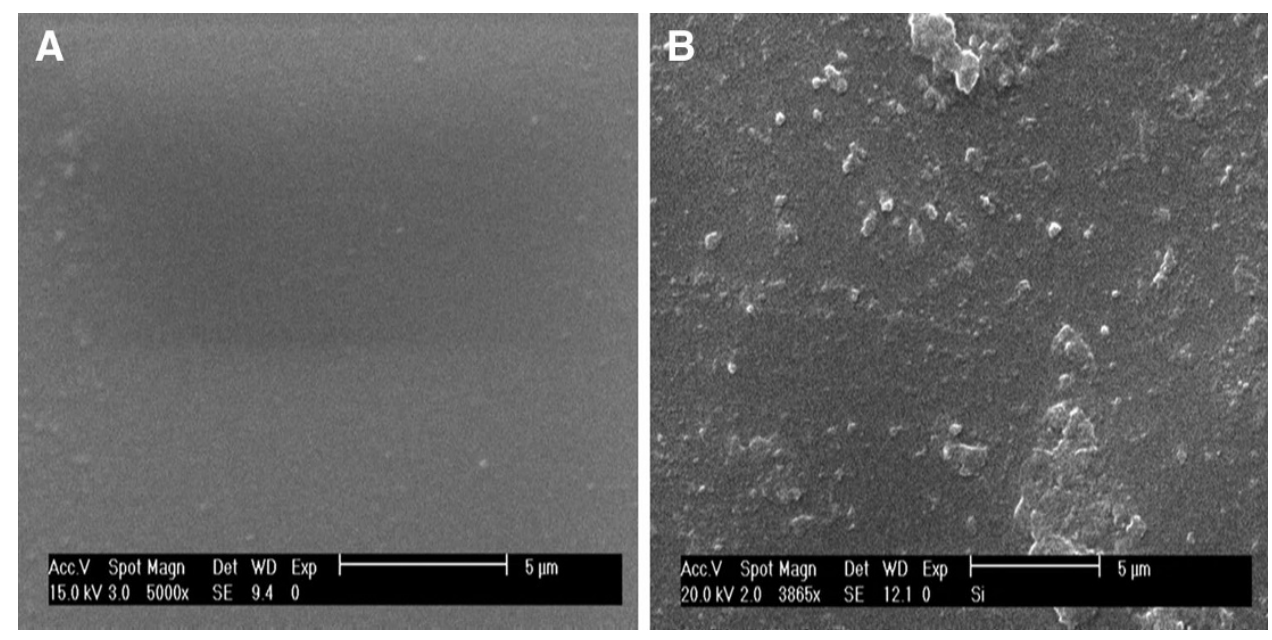

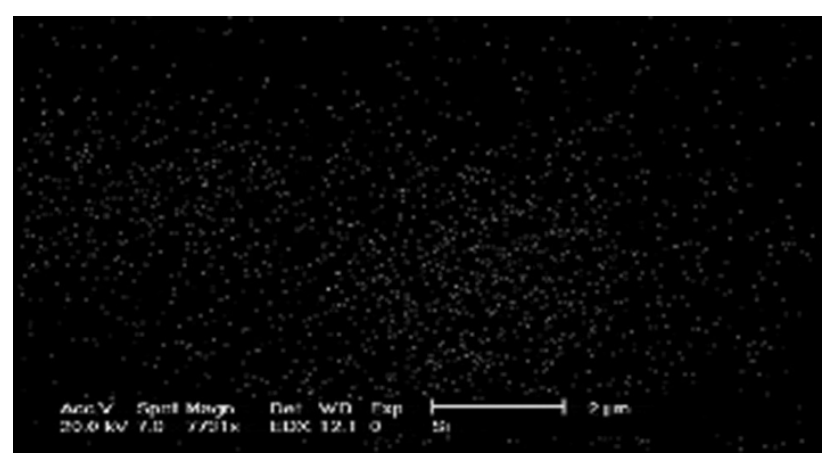

Fig. 6 Dispersion of $\mathrm{Si}$ in surface of the $\mathrm{M}_{4}$ membrane

propyl- $\mathrm{SO}_{3} \mathrm{H}$ on the membrane morphology was clearly observed in these SEM images. With addition of SBA-15propyl- $\mathrm{SO}_{3} \mathrm{H}$ in the membrane matrix, an incensement in the membrane porosity was observed. It can be clearly known that, the clear and smooth surface of $\mathrm{M}_{1}$ membrane change to uneven surface of $\mathrm{M}_{4}$ membrane which is related to $\mathrm{SBA}-15$-propyl- $\mathrm{SO}_{3} \mathrm{H}$ particles.

The $\mathrm{X}$-Ray mapping on the surface of $\mathrm{M}_{4}$ membranes is shown in Fig. 6. The X-Ray mapping is used to show $\mathrm{Si}$ dispersion on surface of membrane. It can be found that silica particles (the bright spots) are evenly distributed in the matrix.

\section{Conductivity measurements}

The water molecules exist in two different forms in nanocomposite membrane. One is the hydrated water that is bound strongly to the $-\mathrm{SO}_{3} \mathrm{H}$ groups. The other is free water that occupies the central space free from the influence of the ionic sites. It is known that the proton transport in membrane follows by two mechanisms (Fig. 7): the first one is the Grotthuss mechanism (hopping), which can be explained as the proton jump from one bound water

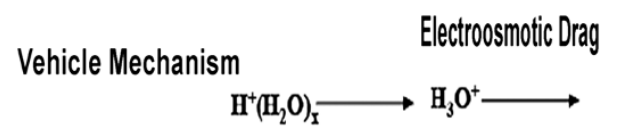

Self-Associated Water

$\left(\mathrm{H}_{2} \mathrm{O}\right)_{\mathrm{y}}$

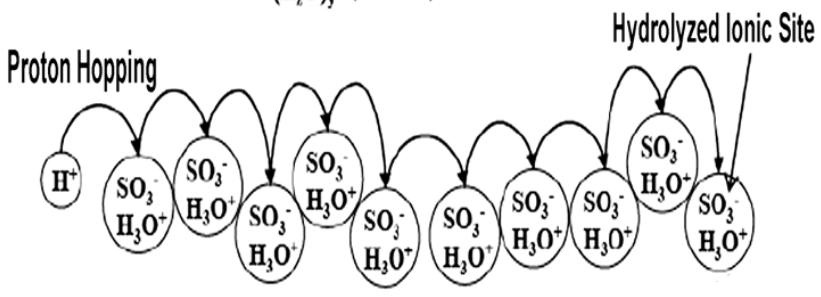

Fig. 7 Hydrogen transport mechanisms in membrane; a vehicle mechanism and $\mathbf{b}$ Proton hopping

molecule $\left(\mathrm{H}_{3} \mathrm{O}^{+} \mathrm{SO}_{3}{ }^{-}\right)$to the next molecule; the second one is the vehicle mechanism, which assume that the proton diffuses together with free water molecules by forming a complex $\left(\mathrm{H}_{3} \mathrm{O}^{+}\right)$and then diffuses intact [33, 34]. Hence, water molecules have important roles in proton conductivity.

Figure 8 shows the AC impedance spectra for different nanocomposite membranes. Descriptions of the different membrane samples used in this work are given in Table 4. Typically, the $\mathrm{R}$ values of the nanocomposite membranes are of the order of 11-130 $\Omega$ and are dependent on the contents of the SBA-15-propyl- $\mathrm{SO}_{3} \mathrm{H}$ and GLA. According to the results, it is clearly seen that the proton conductivity of the nanocomposite membrane decreases when the crosslinking agent is added to membrane. When GLA is added to membrane, the structure of membranes becomes compact and the proton transferring channels become narrow. Hence, the water retention and proton conductivity in the membrane decrease. The proton conductivity of the 


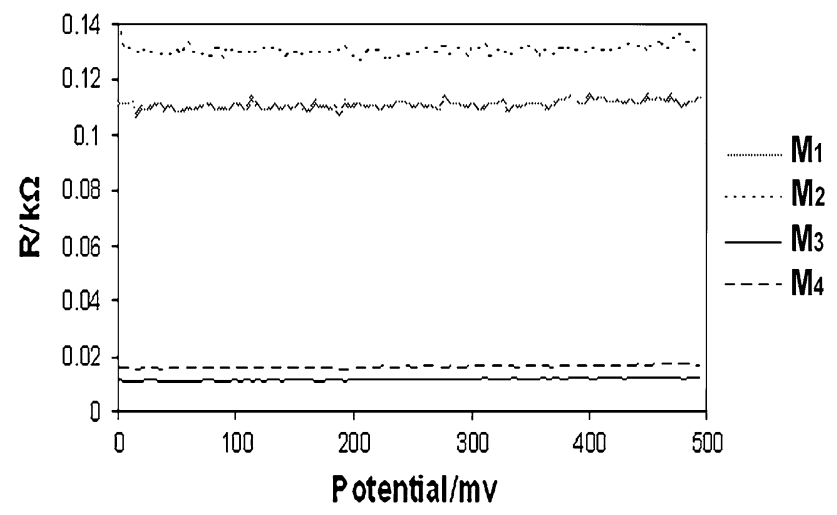

Fig. 8 Impedance spectra of the $M_{1}, M_{2}, M_{3}$ and $M_{4}$ membranes

Table 4 Proton conductivity of membranes

\begin{tabular}{lllcl}
\hline Membranes & $\mathrm{L}(\mathrm{cm})$ & $\mathrm{A}\left(\mathrm{cm}^{2}\right)$ & $\mathrm{R}(\Omega)$ & $\sigma\left(\mathrm{S} \mathrm{cm}^{-1}\right)$ \\
\hline M1 & 0.1 & 1 & 110 & 0.0009 \\
M2 & 0.1 & 1 & 130 & 0.0007 \\
M3 & 0.1 & 1 & 11 & 0.009 \\
M4 & 0.1 & 1 & 15 & 0.006 \\
\hline
\end{tabular}

nanocomposite membrane was enhanced using the sulfonated nanoporous silica matrix. According to Fig. 7, the $\mathrm{SO}_{3} \mathrm{H}$ groups can help membrane to increase proton conductivity by Grotthuss mechanism. The high porous volume of SBA-15-propyl- $\mathrm{SO}_{3} \mathrm{H}$ can keep the water molecules and increased proton conductivity of membrane by vehicle mechanism. As a result, proton may easily enter the pores of sulfonated silica and at the interface between PVA and SBA-15-propyl- $\mathrm{SO}_{3} \mathrm{H}$ and transfer in membrane.

The thermal stability, water uptake and proton conductivity of the PVA/GLA/SBA-15-propyl- $\mathrm{SO}_{3} \mathrm{H}$ membrane, PVA/GLA/SBA-15-ph-SO ${ }_{3} \mathrm{H}$ membrane and Nafion 117 are included in Table 5 for comparison [16, 35, 36]. By considering low proton conductivity of PVA and high density of sulfonated groups in Nafion 117, proton conductivity of the nanocomposite membranes is lower than that of Nafion 117. The results show that, although the proton conductivity of the synthesized nanocomposite membrane has no significant advantage in comparison with Nafion, the water uptake and thermal stability of the nanocomposite membrane are improved. With improved physicochemical and thermal properties, these membranes will be suitable for fuel cell applications as an alternative for Nafion membrane in DMFCs. At end, the results of Table 5 show proton conductivity and $T_{\mathrm{m}}$ of SBA-15-ph$\mathrm{SO}_{3} \mathrm{H}$-based membrane are higher than that of SBA-15propyl- $\mathrm{SO}_{3} \mathrm{H}$-based membrane and the water uptake is equal for both. It was showed that the strength of acid sites
Table 5 Comparison of the Tm, water uptake and proton conductivity of the SBA-15- $\mathrm{RSO}_{3} \mathrm{H}$ membrane, SBA-ph- $\mathrm{SO}_{3} \mathrm{H}$ membrane and Nafion 117 at $25{ }^{\circ} \mathrm{C}$

\begin{tabular}{llll}
\hline Membranes & $T_{\mathrm{m}}\left({ }^{\circ} \mathrm{C}\right)$ & $\begin{array}{l}\text { Water uptake } \\
(\%)\end{array}$ & $\begin{array}{l}\sigma(\mathrm{S} \\
\left.\mathrm{cm}^{-1}\right)\end{array}$ \\
\hline $\begin{array}{l}\text { PVA/GLA/SBA-15- } \\
\text { RSO }\end{array}$ & $150-185$ & 80 & 0.006 \\
$\begin{array}{l}\mathrm{PVA}_{3} \mathrm{GLA} / S B A-p h- \\
\mathrm{SO}_{3} \mathrm{H}\end{array}$ & $170-210$ & 80 & 0.0077 \\
$\mathrm{Nafion} 117$ & 91 & 19.2 & 0.022 \\
\hline
\end{tabular}

of SBA-15-phenyl- $\mathrm{SO}_{3} \mathrm{H}$ is higher than that of SBA-15propyl- $\mathrm{SO}_{3} \mathrm{H}$ [19].

\section{Conclusions}

Organic-inorganic nanocomposite membranes based on PVA/SBA-15-propyl- $\mathrm{SO}_{3} \mathrm{H}$, in which $-\mathrm{SO}_{3} \mathrm{H}$ groups are introduced by co-condensation as hydrophilic inorganic modifier, have been investigated. Enhancement of physicochemical and thermal properties due to addition of glutaraldehyde (GLA) as cross-linking agent in a PVA matrix has been studied. Physicochemical and electrochemical properties of these nanocomposite membranes were dependent on the SBA-15-propyl- $\mathrm{SO}_{3} \mathrm{H}$ content in the membrane matrix as well as the cross-linking density. The characterizations and structure of the membranes were examined and verified by FTIR and SEM techniques. Developed membranes showed good thermal stability, proton conductivity, flexibility and water uptake. The results of differential scanning calorimetry (DSC) show that sulfonated silica decrease and glutaraldehyde can improve the thermal stability of the membrane. With addition of nanoporous silica, the nanocomposite membranes show higher water uptake and proton conductivity. This work demonstrates the promising potential of new nanocomposite membranes for the development of highperformance and high-stability proton exchange membrane fuel cells with improved water uptake and proton conductivity.

Open Access This article is distributed under the terms of the Creative Commons Attribution License which permits any use, distribution, and reproduction in any medium, provided the original author(s) and the source are credited.

\section{References}

1. Wang, Y., Chen, K.S., Mishler, J., Cho, SCh., Adroher, X.C.: A review of polymer electrolyte membrane fuel cells: technology, applications, and needs on fundamental research. Appl. Energy 88, 981-1007 (2011) 
2. Shahi, V.K.: Highly charged proton-exchange membrane: sulfonated poly (ether sulfone)-silica polyelectrolyte composite membranes for fuel cells. Solid State Ionics 177, 3395-3404 (2007)

3. Vinodh, R., Ilakkiya, A., Elamathi, S., Sangeetha, D.: A novel anion exchange membrane from polystyrene (ethylene butylene) polystyrene: synthesis and characterization. Mater. Sci. Eng. B 167, 43-50 (2010)

4. Jannasch, P.: Recent developments in high-temperature proton conducting polymer electrolyte membranes. Colloid Interface Sci 8, 96-102 (2003)

5. Jaafar, J., Ismail, A.F., Mustafa, A.: Physicochemical study of poly(ether ether ketone) electrolyte membranes sulfonated with mixtures of fuming sulfuric acid and sulfuric acid for direct methanol fuel cell application. Mater. Sci. Eng. A 460, 475-484 (2007)

6. Shao, Z.G., Joghee, P., Hsing, I.M.: Preparation and characterization of hybrid Nafion-silica membrane doped with phosphotungstic acid for high temperature operation of proton exchange membrane fuel cells. J. Membr. Sci. 229, 43-51 (2004)

7. Te Hennepe, H.J.C., Bargeman, D., Mulder, M.H.V., Smolders, C.A.: Zeolite-filled silicone rubber membranes part I: membrane preparation and pervaporation results. J. Membr. Sci. 35, 39-55 (1987)

8. Watanabe, M., Uchida, H., Emori, M.: Polymer electrolyte membranes incorporated with nanometer-size particles of Pt and/ or metal-oxides: experimental analysis of the self-humidification and suppression of gas-crossover in fuel cells. J. Phys. Chem. 102, 3129-3137 (1998)

9. Zhou, X.Y., Weston, J., Chalkova, E., Hofmann, M.A., Ambler, C.M., Allcock, H.R., Lvov, S.N.: High temperature transport properties of polyphosphazene membranes for direct methanol fuel cells. Electrochim. Acta 48, 2173-2180 (2003)

10. Staiti, P., Arico, A.S., Baglio, V., Lufrano, F., Passalacqua, E., Antonucci, V.: Hybrid Nafion-silica membranes dipped with hpa for applications in DMFC. Solid State Ionics 145, 101-107 (2001)

11. Won, J.H., Lee, H.J., Yoon, K.S., Hong, Y.T., Lee, S.Y.: Sulfonated SBA-15 mesoporous silica-incorporated sulfonated poly(phenylsulfone) composite membranes for low-humidity proton exchange membrane fuel cells: anomalous behavior of humidity-dependent proton conductivity. Int. J. Hydrog. Energy 37, 9202-9211 (2012)

12. Salarizadeh, P., Javanbakht, M., Abdollahi, M., Naji, L.: Preparation, characterization and properties of proton exchange nanocomposite membranes based on poly(vinyl alcohol) and poly(sulfonic acid)-grafted silica nanoparticles. Int. J. Hydrog. Energy 38, 5473-5479 (2012)

13. Yang, C.C., Lee, Y.J., Yang, J.M.: Direct methanol fuel cell (DMFC) based on PVA/MMT composite polymer membranes. J. Power Sources 188, 30-37 (2009)

14. Guzmán, C., Alvarez, A., García, J.L., Torres, S.M.D., Arriaga, L.G.: Composite membranes based on SBA-15 and SBA-16 evaluated at high temperature and low relative humidity fuel cell conditions. Int. J. Electrochem. Sci. 6, 4787-4797 (2011)

15. Salarizadeh, P., Abdollahi, M., Javanbaht, M.: Modification of silica nanoparticles with hydrophilic sulfonated polymers by using surface-initiated redox polymerization. Iranian Polym J 21, 661-668 (2012)

16. Beydaghi, H., Javanbakht, M., Salar Amoli, H., Badiei, A., Khaniani, Y., Ganjali, M., Norouzi, P., Abdouss, M.: Synthesis and characterization of new proton conducting hybrid membranes for PEM fuel cells based on poly (vinyl alcohol) and nanoporous silica containing phenyl sulfonic acid. Int. J. Hydrog. Energy 36, 13310-13316 (2011)
17. Hooshyari, Kh, Javanbakht, M., Naji, L., Enhessari, M.: Nanocomposite proton exchange membranes based on Nafion containing $\mathrm{Fe}_{2} \mathrm{TiO}_{5}$ nanoparticles in water and alcohol environments for PEMFC. J. Membr. Sci. 454, 74-81 (2014)

18. Gomes, A.D.S., Filho, J.C.D.: Hybrid membranes of PVA for direct ethanol fuel cells (DEFCs) applications. Int. J. Hydrog. Energy 37, 6246-6252 (2012)

19. Usai, E.M., Sini, M.F., Meloni, D., Solinas, V., Salis, A.: Sulfonic acid-functionalized mesoporous silicas: microcalorimetric characterization and catalytic performance toward biodiesel synthesis. Microporous Mesoporous Mater. 179, 54-62 (2013)

20. Zeng, Q.H., Liu, Q.L., Broadwell, I., Zhu, A.M., Xiong, Y., Tu, X.P.: Anion exchange membranes based on quaternized polystyrene-block-poly(ethylene-ran-butylene)-block-polystyrene for direct methanol alkaline fuel cells. J. Membr. Sci. 349, 237-243 (2010)

21. Feng, F., Yang, Zh, Coutinho, D.H., Ferraris, J.P., Balkus Jr, K.J.: Synthesis of proton conducting tungstosilicate mesoporous materials and polymer composite membranes. Microporous Mesoporous Mater. 81, 217-234 (2005)

22. Zhao, D., Huo, Q., Feng, J., Chmelka, B.F., Stucky, G.D.: Nonionic triblock and star diblock copolymer and oligomeric surfactant syntheses of highly ordered, hydrothermally stable, mesoporous silica structures. J. Am. Chem. Soc. 120, 6024-6036 (1998)

23. Hassan, C.M., Peppas, N.A.: Advances in Polymer Science, vol. 153. Springer-Verlag, Berlin (2000)

24. Peppas, N.A., Stauffer, S.R.: Reinforced uncrosslinked poly (vinyl alcohol) gels produced by cyclic freezing-thawing processes: a short review. J. Control. Release 16, 305-310 (1991)

25. Kuznetsov, P.N., Kuznetzova, L.I., Zhyzhaev, A.M., Pashkov, G.L., Boldyrev, V.V.: Ultra fast synthesis of metastable tetragonal zirconia by means of mechanochemical activation. Appl. Catal. A Gen 227, 299-307 (2002)

26. Ansur, H.S., Sadahira, C.M., Souza, A.N., Mansur, A.A.P.: FTIR spectroscopy characterization of poly (vinyl alcohol) hydrogel with different hydrolysis degree and chemically crosslinked with glutaraldehyde. Mater. Sci. Eng. C 28, 539-548 (2008)

27. Kang, M.S., Choi, Y.J., Moon, S.H.: Water-swollen cationexchange membranes prepared using poly (vinyl alcohol) (PVA)/ poly (styrene sulfonic acid-co-maleic acid) (PSSA-MA). J. Membr. Sci. 207, 157-170 (2002)

28. Tseng, ChY, Ye, YSh, Kao, K.Y., Joseph, J., Shen, WCh., Rick, J., Hwang, B.J.: Interpenetrating network-forming sulfonated poly(vinyl alcohol) proton exchange membranes for direct methanol fuel cell applications. Int. J. Hydrog. Energy 36, 11936-11945 (2011)

29. Timofeeva, M.N., Jhung, S.H., Hwang, Y.K., Kim, D.K., Panchenko, V.N., Melgunov, M.S.: Ce-silica mesoporous SBA-15type materials for oxidative catalysis: synthesis, characterization, and catalytic application. Appl. Catal. A Gen 317, 1-10 (2007)

30. Linder, N.B., Dosseh, G., Simonesco, ChA, Audonnet, F.: Imperor-Cler M. SBA-15 synthesis: are there lasting effects of temperature change within the first 10 min of TEOS polymerization. Mater. Chem. Phys. 108, 73-81 (2008)

31. Nagarale, R.K., Gohil, G.S., Shahi, V.K., Rangarajan, R.: Organic-inorganic hybrid membranes: thermally stable cationexchange membrane by sol-gel method. Macromolecules 37, 10023-10030 (2004)

32. Kim, D.S., Park, H.B., Rhim, J., Lee, Y.M.: Preparation and characterization of crosslinked $\mathrm{PVA} / \mathrm{SiO}_{2}$ hybrid membranes containing sulfonic acid groups for direct methanol fuel cell applications. J. Membr. Sci. 240, 37-48 (2004)

33. Kim, D.S., Liu, B., Guiver, M.D.: Influence of silica content in sulfonated poly(arylene ether ether ketone ketone)(SPAEEKK) 
hybrid membranes on properties for fuel cell application. Polymer 47, 7871-7880 (2006)

34. Rodriguez, C.M.B., Paleta, M.G.A.R., Marquezv, J.A.R., Delavega, J.R.G.: Effect of a rigid gas diffusion media applied as distributor of reagents in a PEMFC in operation, part II: wet gases. Int. J. Electrochem. Sci. 5, 414-428 (2010)

35. Pang, J., Zhang, H., Li, X., Wang, L., Liu, B., Jiang, Zh: Synthesis and characterization of sulfonated poly(arylene ether)s with sulfoalkyl pendant groups for proton exchange membranes. J. Membr. Sci. 318, 271-279 (2008)

36. Kim, S.O., Kim, J.S.: Preparation of hybrid proton conductor by sol-gel process from Nafion solution. Macromol. Res. 10, 174-177 (2002) 